\title{
PENGEMBANGAN E-MATERI BERBASIS MATA KULIAH PADA PEMBELAJARAN JARAK JAUH (E-LEARNING)
}

\author{
Doni Septu Marsa Ibrahim ${ }^{1}$, Yuyun Febriani ${ }^{2}$ \\ Universitas Hamzanwadi \\ 1janganletih@gmail.com,2yuyun_sakura@yahoo.com
}

\begin{abstract}
Abstrak
Penelitian ini bertujuan untuk 1. Mengetahui tingkat kebutuhaun pengguanan internet di kalangan mahasiswa Universitas Hamzanwadi. 2. Untuk menghasilkan e-materi yang dikembangkan berdasarkan mata kuliah 3. Menghasilkan purwarupa LMS untuk pembelajaran daring. E-materi yang dikembangkan berbasis mata kuliah pada program studi Pendidikan Guru Sekolah Dasar (PGSD) Universitas Hamzanwadi. Untuk dapat mewujudkannya maka dilakukan penelitian Pengembangan yang digunakan merujuk pada model pengembangan Borg dan Gall dengan tahapan yang pertama studi kebutuhan material pembelajaran dilanjutkan dengan merancang desain, menentukan konten material dan aset media, memvalidasi sampai dengan pembuatan produk akhir. E-materi yang dikembangkan terdiri atas sub-sub materi yang tergabung dalam satu paket material pembelajaran.Hasil penelitian ini diharapkan dapat meningkatkan kemampuan peneliti untuk dapat menyajikan material pembelajaran yang bervariasi dalam proses pembelajaran.
\end{abstract}

Kata kunci : e-materi, pembelajaran jarak jauh (e-learning) 


\section{PENDAHULUAN}

Porsi penggunaan teknologi dan informasi oleh masyarakat yang mencakup berbagai bidang kehidupan seperti bidang ekonomi, sosial dan pendidikan belum cukup proporsional. Survei yang dilakukan Mars Indonesia mengungkap bahwa 90,5 juta orang Indonesia telah terhubung ke internet. Penggunaan teknologi pada bidang ekonomi dan sosial mengambil porsi terbesar dari pada bidang pendidikan. Penggunaan teknologi di bidang ekonomi dapat dilihat dari pertumbuhan $e$ commerce atau online shop yang begitu pesat. Data Asosiasi E-commerce Indonesia (idEA) tahun 2016 mencatat tiga tahun yang lalu anggotanya hanya berjumlah 9 perusahaane-commerce. Namun saat ini sudah beranggotakan 185 perusahaan. Begitu juga hal nya dengan bidang sosial, Indonesia masuk dalam kelompok terbesar penggunaan sosial media seperti Facebook, Twiter, Instagram dan media sosial lainnya. Menurut Laporan riset We Are Social dan Hootsuite Indonesia menduduki peringkat ke-4 di dunia dengan pengguna Facebook paling aktif.

Masyarakat begitu cepat mengadopsi perkembangan teknologi dalam kehidupan sehari hari dan mengaplikasikannya dalam berinteraksi dengan orang lain. Seringkali interaksi tersebut tidak menghasilkan hal yang bernilai positif namun justru menggunakan media teknologi untuk hal-hal yang bersifat negatif. Dari segi usia masyarakat usia remaja menjadi pengguna terbesar. Dari usia tersebut pengguna sosial media berasal dari usia sekolah. Penggunaan media pada bidang pendidikan sangat rendah karena kurangnya sumberdaya yang mampu menciptakan aplikasi pembelajaran atau program pendidikan yang ramah bagi remaja usia sekolah yang bisa menyaingi aplikasi sosial media saat ini. Ada beberapa aplikasi pembelajaran seperti Quiper Video, Edmodo dan lain sebagainya belum dapat memenuhi kebutuhan konten aplikasi pendidikan yang begitu besar. Remaja usia sekolah merupakan pasar yang sangat potensial sebagai pengguna aplikasi pembelajaran. Oleh karena itu pengembangan aplikasi maupun program yang berbasis teknologi masih memiliki pangsa pasar yang begitu besar untuk dikembangkan lebih luas lagi. Pengembangan aplikasi pembelajaran mutlak dilakukan agar manfaat teknologi sejauh ini yang begitu modern dapat digunakan sebaik mungkin untuk memperbaiki kualitas pendidikan. 
1. Bagaimana pengembangan e-materi berbasis mata kuliah pada pembelajaran jarak jauh?

2. Bagaimana kelayakan hasil pengembangan e-materi berbasis mata kuliah pada pembelajaran jarak jauh?

Produk yang diakan dihasilkan berupa e-materi berbasis mata kuliah yang dapat digambarkan sebagai materi perkuliahan pada umumnya yang dikemas dalam bentuk paket-paket pembelajaran atau kegiatan belajar (KB) pembelajaran. Masing-masing KB terdiri dari materi, tugas, dan tes, sehingga penelitian ini dibatasi pada pengembangan yang dapat diuraikan sebagai berikut; 1) Pengembangan e-materi yang disusun dalam bentuk buku panduan pembuatan dan panduan penggunaan pengembangan e-materi. 2) Produk pengembangan berupa materi perkuliahan dalam bentuk e-materi berbasis mata kuliah. 3)Website e-materi untuk mengakses pembelajaran melalui internet.

\section{E-Learning atau Pembelajaran Jarak Jauh (PJJ)}

E-Learning mengacu pada pembelajaran yang memanfaatkan media elektronik dan teknologi informasi dalam pembelajaran. Pembelajaran ini juga disebut pembelajaran secara online (daring). Menurut Tafiardi (2005) E-learning adalah suatu model pembelajaran yang dibuat dalam format digital melalui pe-rangkat elektronik. Pembelajaran menggunakan e-learning adalah proses pembelajaran efektif yang diciptakan dengan cara menggabungkan konten pembelajaran yang disampaikan secara digital dengan menggunakan perangkat-perangkat elektronik untuk menyampaikan materi pelajaran (Ibrahim, 2014) Pembelajaran daring (dalam jaringan) membutuhkan sumberdaya material memadai yang dapat mengakomodir kebutuhan dan karakteristik pembelajaran secara daring. Pembelajaran daring memiliki keluesan dalam medium dan tidak terikat oleh ruang dan waktu. "Some terms are frequently interchanged with E-learning include: 1) Online learning/ education, 2) Distance education/ learning, 3) Technology-based training, 4) Webbased learning/training, 5) Computer-based training/leaning from a digitalization" (Desai, 2014).

Fokus utama pembelajaran jarak jauh terletak pada peserta didik sehingga lebih mandiri dan bertanggungjawab terhadap pembelajarannya (Sumardi, K. dan Supriawan, D., 2011). Peserta didik berperan lebih aktif dalam membuat rencana dan 
mencari bahan pembelajaran sehingga pengalaman belajar lebih bermakna. Guna memenuhi kebutuhan belajar yang lebih kompleks pendidik tidak hanya sekedar meng-upload materi di internet melainkan harus ada mekanisme khusus yang dapat melibatkan siswa dalam belajar, ada ruang diskusi dan assesment hasil belajar, maka e-learning harus di dukung online learning yang bersifat Learning Management System(LMS).

\section{Website}

Situs web atau dalam Bahasa inggris website menurut Wikipedia merupakan halaman web yang saling berhubungan yang secara umum tesimpan dalam peladen (server) yang berisi informasi perorangan, kelompok, maupun oraganisasi yang dapat di akses melalui jaringan internasional maupun jaringan lokal. Halaman website umumnya ada dua jenis yaitu website statis dan website dinamis. Website statis umumnya hanya menampilkan informasi yang hanya bias dibaca oleh pengguna sedangkan website dinamis menyediakan fitur bagi pengguna untuk bisa memberikan kontribusi pada website. Bebrapa kelebihan dan kekurangan website statis. (Hardy, 2015)

\section{a. Kelebihan Website Statis}

Cepat untuk dikembangkan

Efisien untuk dikembangkan

Efisien saat disimpan pada web hosting

\section{b. Kekurangan Website Statis}

Membutuhkan tenaga ahli khusus untuk melakukan perubahan

Situs menjadi kurang bermanfaat bagi pengunjung

Konten website yang usang

Sedangkan website dinamis memiliki konten yang bisa beradaptasi menyesuaikan interaksi dari pengunjung. Perubahan pada data dijalankan oleh aplikasi secara berkala, seperti pada website berita memiliki berberapa kelebihan dan kekurangan.

\section{a. Keuntungan Website Dinamis}

Memiliki banyak fitur tambahan

Lebih mudah untuk dikembangkan 
Lebih mudah menambah konten baru yang menarik pengunjung dari search engine

Memiliki fitur yang memudahkan pengelola dan pengguna untuk bekerjasama

\section{b. Kekurangan Website Dinamis}

Membutuhkan waktu lama dan dana lebih untuk pengembangan

Membutuhkan biaya hosting lebih mahal

Berdasarkan fungsinya website memiliki banyak fungsi diantaranya: Company Profile, E-Commerce, Archive, Dating, Government, Personal, Entertainment, News Portal, Blog, Community, Educational, Search Engine, Gallery, Social Media, Social Bookmarking, Social News dan lain-lain.

\section{E-Materi}

Materi pembelajaran selama ini disajikan dalam bentuk material buku baik buku fisik maupun dalam e-book. Kelemahannya adalah tidak bisa menciptakan interaksi antar pembelajar. E-materi disusun sedemikian rupa dengan bantuan Learning Management System untuk dapat menciptakan pengalaman belajar dalam bentuk diskusi secara online. Untuk merumuskan e-materi pembelajaran dapat dibagi menjadi beberapa langkah. Langkah ini mengacu pada Pengembangan Model Desain Pembelajaran yang dikembangkan oleh Uwes A. C. (2017) yang oleh disarikan oleh peneliti dalam langkah-langkah sebagai berikut; (1) menentukan setting pembelajaran (untuk mengetahui setting pembelajaran yang akan dimuat dalam e-materi yaitu yang bersifat asinkronous). (2) merangcang aktivitas pembelajaran, (3) merangkai alur pembelajaran (4) menyusun assessment hasil belajar. Peneliti dalam hal ini membuat rumusan e-materi yang teridiri dari 3 komponen minimal yang harus ada dalam e-materi ;

1) Materi,

Materi terdiri atas 1) deskripsi materi, dalam bentuk text (format pdf), 2) simulasi dalam bentuk video atau flash, gif, 3) slide presentasi.

2) Tugas, dan

3) Tes

Aset-aset digital dimuat pada materi, tugas dan tes yang disesuaikan dengan kebutuhan. Keragaman format asset-aset digital diarahkan untuk membuat 
pembelajaran semakin efektif dan efisien dan semakin mempermudah pemahaman mahasiswa.

\section{METODE PENELITIAN}

Penelitian ini menggunakan pendekatan pengembangan yang diadopsi dari model pengembangan Borg \& Gall yang dalam bukunya mengatakan pengembangan adalah proses memvalidasi produk dalam hal peneliti menterjemahkan bahwa produk yang dihasilkan merupakan serangkaian uji coba dan revisi sampai menghasilkan produk yang benar-benar layak untuk digunakan (desiminasi). Model ini memberikan kesempatan kepada peneliti untuk dapat menghadirkan produk yang benar-benar valid melalui mekanisme validasi secara yang dapat dilakukan berkalikali hingga memperoleh hasil yang valid dan memuaskan. Secara garis besar langkah-langkah pengembangan terdiri atas; (1) studi pendahuluan, (2) perencanaan, (3) pengembangan, dan (4) desiminasi. Pada tahap (3) yaitu pengembangan termasuk didalamnya uji coba dapat berkembang sesuai dengan kebutuhan peneliti sehingga tercipta produk akhir yang valid. Untuk lebih jelasnya dapat dilihat pada skema pengembangan yang disajikan pada bagan di bawa ini.

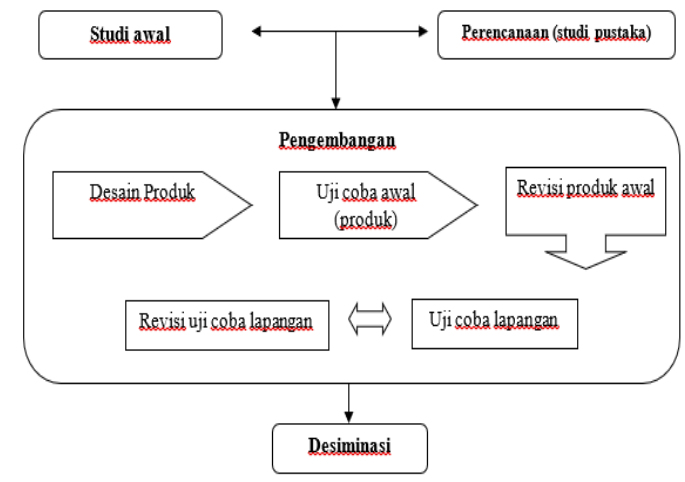

Gambar 1. Skema Model Pengembangan

\section{A. Prosedur Pengembangan}

1. Studi pendahuluan

Penelitian pendahuluan ini ditujukan untuk mengetahui bagaimana kebiasaan mahasiswa dalam menggunakan dalam menggunakan internet. Pada penyusunan instrument peneliti memfokuskan pada tiga aspek yaitu. 1) Waktu, 2) Alat, (termasuk komponen biaya), 3) Content atau isi dari penggunaan internet tersebut. Peneliti menyebarkan kuisioner yang terdiri atas 10 pertanyaan dengan kisi-kisi pertanyaan sebagai berikut: 
a. Menyusun Instrumen Angket Untuk Studi Pendahuluan

Insrrumen angket yang digunakan untuk studi awal dalam penelitian ini dapat dilihat pada tabel di bawah ini:

Tabel 1. Kisi-Kisi Instrumen Angket : Penggunaan Internet pada Mahasiswa di Lingkup Universitas Hamzanwadi

\begin{tabular}{|l|l|l|}
\hline \multicolumn{1}{|c|}{ Aspek } & \multicolumn{1}{|c|}{ Indikator } & \multicolumn{1}{|c|}{ Jml Pertanyaan } \\
\hline Waktu & $\begin{array}{l}\text { Dapat mengatur waktu } \\
\text { menggunakan/mengakses internet }\end{array}$ & 3 \\
\hline $\begin{array}{l}\text { Alat dan } \\
\text { Komponen } \\
\text { Biaya }\end{array}$ & $\begin{array}{l}\text { Dapat menggunakan perangkat } \\
\text { untuk mengakses internet }\end{array}$ & 1 \\
\cline { 2 - 4 } & $\begin{array}{l}\text { Dapat mengelola biaya pulsa } \\
\text { internet }\end{array}$ & 2 \\
\hline Isi & $\begin{array}{l}\text { Dapat menggunakan berbagai jenis } \\
\text { layanan Internet }\end{array}$ & 3 \\
\cline { 2 - 4 } & $\begin{array}{l}\text { Dapat menentukan isi content - } \\
\text { content } \text { Internet }\end{array}$ & 1 \\
\hline
\end{tabular}

*Instrumen Angket : Penggunaan Internet pada Mahasiswa di Lingkup Universitas Hamzanwadi dapat dilihat pada lampiran

b. Analisis Data hasil angket

Data hasil angket akan dianalisis menggunakan deskriptif persentase. Rumus untuk mengolah data yang berupa deskriptif persentase (Sudijono, 2009: 43) adalah sebagai berikut:

$$
P=\frac{f}{N} \times 100 \%
$$

Keterangan :

f : Frekwuensi yang sedang dicari presentasinya

$\mathrm{N}$ : Number of case (jumlah frekuensi/ banyaknya individu), terkait dengan kemudahan, kesengangan dan keamanan anak saat melakukan kegiatan.

$\mathrm{P}$ : Angka presentase

Apabila datanya berupa persentase, proporsi maupun rasio, maka kesimpulan yang dapat diambil, disesuaikan dengan permasalahannya. Berikut ini penggolongan persentase kategori yang akan digunakan adalah: 
Tabel 2. Deskriptif Persentase (Sudijono, 2009: 43)

\begin{tabular}{|l|l|}
\hline Presentase & Keterangan \\
\hline $80 \%-100 \%$ & Tinggi \\
\hline $60 \%-79 \%$ & Cukup Tinggi \\
\hline $50 \%-59 \%$ & Kurang Tinggi \\
\hline$<50 \%$ & Rendah \\
\hline
\end{tabular}

Instrumen angket diberikan ke 100 responden (mahasiswa di lingkup Universitas Hamzanwadi) secara acak. Responden yang diberikan berumur sekitar 18-20 tahun. Analisis data angket ini meliputi aspek waktu, alat dan komponen biaya, serta isi. Secara lengkap dapat dilihat pada tabel di bawah ini:

Tabel 3 . Data Analisis

\begin{tabular}{|c|c|c|c|}
\hline Aspek & Indikator & Pernyataan & $\begin{array}{c}\text { Persentas } \\
\text { e }\end{array}$ \\
\hline Waktu & $\begin{array}{l}\text { Dapat mengatur waktu } \\
\text { menggunakan/mengakses } \\
\text { internet }\end{array}$ & $\begin{array}{l}\text { 1. Keseringan } \\
\text { menggunakan } \\
\text { internet: } \\
\text { a.Setiap hari } \\
\text { b.Dua hari sekali } \\
\text { c.Seminggu Sekali } \\
\text { 2. Waktu mengakses } \\
\text { internet: } \\
\text { a.Pagi } \\
\text { b.Siang } \\
\text { c.Malam } \\
\text { d.Semua waktu } \\
\text { 3. Lama waktu yang } \\
\text { dihabiskan: } \\
\text { a.Kurang dari } 1 \text { jam } \\
\text { b.1-2 jam } \\
\text { c.Lebih dari } 2 \text { jam }\end{array}$ & $\begin{array}{l}90 \% \\
4 \% \\
6 \% \\
3 \% \\
3 \% \\
24 \% \\
70 \%\end{array}$ \\
\hline
\end{tabular}




\begin{tabular}{|c|c|c|c|}
\hline & & & $33 \%$ \\
\hline \multirow[t]{2}{*}{$\begin{array}{l}\text { Alat dan } \\
\text { Kompo-nen } \\
\text { Biaya }\end{array}$} & $\begin{array}{l}\text { Dapat menggunakan } \\
\text { perangkat untuk mengakses } \\
\text { internet }\end{array}$ & \begin{tabular}{l} 
1. Perangkat yang \\
digunakan untuk \\
mengakses \\
internet:\} $\\
{\text { a. Laptop/computer }} \\
{\text { b. Hand phone }} \\
{\text { (HP) }} \\
{\text { c. Tablet }}$ & $\begin{array}{l}94 \% \\
4 \%\end{array}$ \\
\hline & $\begin{array}{l}\text { Dapat mengelola biaya pulsa } \\
\text { internet }\end{array}$ & $\begin{array}{l}\text { 1. Menyediakan biaya } \\
\text { tertentu untuk pulsa } \\
\text { internet dan pulsa } \\
\text { telepon/sms: } \\
\text { a. Lebih banyak } \\
\text { pulsa internet dari } \\
\text { pada telepon/sms } \\
\text { b. Lebih banyak } \\
\text { pulsa telpon/sms } \\
\text { dari pada pulsa } \\
\text { internet } \\
\text { c. Sama banyak } \\
\text { pulsa internet dan } \\
\text { pulsa telepon/sms } \\
\text { 2. Jumlah } \\
\text { pengeluaran pulsa } \\
\text { internet selama satu } \\
\text { bulan } \\
\text { a. } 10 \mathrm{~K}-30 \mathrm{~K} \text { K- } 30 \mathrm{~K}-50 \mathrm{~K} \text { K } \\
\text { d. Lebih dari } 100 \mathrm{~K}\end{array}$ & $20 \%$ \\
\hline
\end{tabular}
\end{tabular}




\begin{tabular}{|c|c|c|c|}
\hline & & & $\begin{array}{l}37 \% \\
12 \% \\
1 \%\end{array}$ \\
\hline Isi & $\begin{array}{l}\text { Dapat menggunakan berbagai } \\
\text { jenis layanan Internet }\end{array}$ & $\begin{array}{l}\text { 1. Kategori yang } \\
\text { a. Mering diakses: } \\
\text { artikel, dll } \\
\text { b. Social media } \\
\text { c. Chat } \\
\text { d. Layanan } \\
\text { VOD/Streaming } \\
\text { 2. Pernah mencari } \\
\text { materi perkuliahan } \\
\text { dari internet: } \\
\text { a. Ya } \\
\text { b. Tidak } \\
\text { 3. Mengetahui nama } \\
\text { web untuk mencari } \\
\text { materi perkuliahan } \\
\text { di internet: } \\
\text { a. Ya } \\
\text { b. Tidak }\end{array}$ & $\begin{array}{l}63 \% \\
73 \% \\
70 \% \\
45 \% \\
87 \% \\
\\
12 \% \\
64 \% \\
36 \%\end{array}$ \\
\hline & $\begin{array}{l}\text { Dapat menentukan isi content } \\
\text { - content Internet }\end{array}$ & $\begin{array}{ll}\text { 1. } & \text { Kepercayaan } \\
& \text { terhadap konten } \\
& \text { materi } \\
& \text { perkuliahan di } \\
& \text { internet: } \\
\text { a. Sangat Percaya } \\
\text { b. Agak Percaya } \\
\text { c. Tidak Percaya } \\
\text { d. Sangat Tidak } \\
\text { Percaya }\end{array}$ & $\begin{array}{l}35 \% \\
\\
64 \% \\
1 \% \\
0 \%\end{array}$ \\
\hline
\end{tabular}


Berdasarkan data tabel di atas dapat dilihat bahwa item yang memiliki persentase tinggi (80-100 \%) meliputi: keseringan menggunakan internet, $90 \%$ responden menggunakan waktu setiap hari untuk menggunakan internet; dapat menggunakan perangkat untuk mengakses internet, $94 \%$ responden menggunakan hand phone untuk mengaksesnya; dan dapat menggunakan berbagai jenis layanan internet, $87 \%$ responden pernah mencari materi perkuliahan dari internet.

Selanjutnya item dengan persentase cukup tinggi (60-79 \%) meliputi : waktu menggunakan internet, $71 \%$ responden menghabiskan waktu di semua waktu untuk mengakses internet; pengelolaan biaya pulsa internet, $70 \%$ responden memiliki lebih banyak pulsa internet (kuota) dibandingkan pulsa telepon/sms; dapat menggunakan berbagai jenis layanan internet meliputi kategori yang sering diakses, $63 \%$ responden membaca artikel dan berita, $73 \%$ menggunakan sosial media, dan $70 \%$ menggunakan chat dan mengetahui web untuk mencari materi perkuliahan dengan 64 $\%$ responden mengetahuinya; dapat menentukan content dengan $64 \%$ responden agak percaya dengan konten di internet.

Untuk item lainnya seperti lama waktu yang dihabiskan dan pengelolaan pembiayaan untuk mengakses internet selama satu bulan berada pada interval rendah dengan persentase kurang dari $50 \%$. Data ini menunjukkan tingginya penggunaan internet di kalangan mahasiswa di Universitas Hamzanwadi, sehingga diperlukan usaha untuk mengendalikan pengunaannya agar tidak berdampak negative terhadap perkembangan akademis mahasiswa. Salah satunya seperti dengan mengembangkan e-materi untuk kegiatan akademis/perkuliahan mahasiswa.

\section{HASIL DAN PEMBAHASAN}

\section{A. Hasil}

Hasil studi pendahuluan menunjukkan bahwa mahasiswa memiliki intensitas penggunaan internet yang cukup tinggi sehingga jika tidak dikendalikan maka akan berdampak negatif terhadap perkembangan akademis mahasiswa. Hal ini semakin diperburuk oleh konten-konten yang tersedia untuk mendukung kegiatan belajar mahasiswa masih kurang dan lebih banyak didominasi oleh konten-konten konten hiburan seperti chating, permainan, menonton video dll yang tidak ada kaitannya dengan materi perkuliahan. Berdasarkan hal tersebut peneliti mencoba melakukan kajian studi pustaka untuk mencari solusi bagaimana agar mahasiswa tetap dapat 
menggunakan internet tetapi dapat memberikan dampak positif terhadap hasil studi. Hasil studi pendahuluan menunjukkan Intensitas tingginya penggunaan internet di kalangan mahasiswa di Universitas Hamzanwadi terlihat dengan tingginya persentase keseringan mahasiswa mengakses internet. Mahasiswa $90 \%$ mengakses internet setiap hari dengan interval waktu yang bervariasi di semua waktu. Ini tentunya akan menjadi dasar yang sangat baik dalam mengembangkan e-materi. Mahasiswa dapat menggunakan sebagian besar waktunya untuk mengakses hal-hal positif dalam mengembangkan kegiatan akademisnya.

Pengembangan e-materi ini sangat penting untuk dikembangkan selain karena intensitas tingginya akses internet dari mahasiswa, banyaknya layanan atau kategori yang diakses seperti: browsing internet, berita, dan lain-lain (63\%), sosial media (73\%), Chat (70 \%), dan layanan VOD/Streaming (45\%). Hampir semua jenis layanan di internet diakses oleh mahasiswa. Selain itu, mahasiswa juga memiliki pengalaman mencari materi perkuliahan dengan persentase tinggi $(87 \%)$ dengan memanfaatkan berbagai web seperti Google dan Wikipedia. Tingkat kepercayaan mahasiswa terhadap konten-konten materi perkuliahan yang dapat diakses dari internet sangat besar dilihat dari variasi tingkat kepercayaannya seperti: sangat percaya (35\%), agak percaya (64\%), tidak percaya (1\%), dan sangat tidak percaya $(0 \%)$. Hanya $1 \%$ saja mahasiswa yang tidak percaya dengan konten materi untuk akademis yang dapat mereka akses dari internet. Tentunya ini membuat pengembangan e-materi menjadi sangat penting untuk dikembangkan. Kepercayaan mahasiswa harus benar-benar dimanfaatkan untuk mengembangkan hal yang penting dalam mengembangkan akademis mereka.

Apalagi ini sangat didukung dengan kemampuan ekonomi mahasiswa dalam menyediakan biaya tertentu untuk pulsa internet (kuota). Jumlah pengeluaran biaya yang mereka keluarkan untuk pulsa internet selama satu bulan bervariasi mulai dari Rp 10.000,00 - Rp 100.000,- dan kondisi mahasiswa adalah mereka lebih banyak pulsa internet (kuota) dibandingkan dengan pulsa telpon/sms (70 \%). Kemampuan mahasiswa secara ekonomi dalam menyediakan pulsa internet (kuota) sangat mendukung pelaksanaan pengembangan e-materi ini. Mahasiswa secara mandiri mampu menyediakan sumber bagi pelaksanaan pengembangan ini, sehingga e-materi 
yang dikembangkan dapat diakses dimanapun dan kapanpun tanpa harus mengharapkan adanya fasilitas internet gratis yang diberikan oleh kampus.

Yang harus menjadi pertimbangan dalam mengembangkan e-materi ini adalah emateri yang dikembangkan harus dapat diakses melalui berbagai jenis perangkat terutama hand phone. Hal ini didasarkan bahwa sebagian besar mahasiswa mengakses internet menggunakan hand phone (94\%), 35\% menggunakan laptop/komputer, dan hanya $4 \%$ yang menggunakan tablet. Ini tentunya menjadi pertimbangan bagi peneliti untuk mengembangkan e-materi yang dapat diakses oleh berbagai perangkat.

Berdasarkan hal tersebut peneliti menawarkan suatu bentuk konten-konten materi perkuliahan yang dikemas dalam bentuk e-materi yang dapat diakses melalui internet. E-materi disesuaikan dengan jenis-jenis konten yang menarik tidak hanya berupa materi text, tetapi dilengkapi dengan video, simulasi dan slide yang terhimpun menjadi satu dalam satu topik kegiatan belajar yang sesuai dengan mata kuliah.

\section{B. Pembahasan}

Luaran yang dicapai berupa draf produk yang dikemas dalam bentuk paket-paket pembelajaran atau kegiatan belajar yang nantinya akan di tempatkan pada halaman website sehingga dapat diakses melalui internet. Draf produk dibuat dalam bentuk draf e-materi (terlampir) Website didesain dengan template yang familiar (ramah) dengan materi-materi perkuliahan dalam penyajiannya dibuat sedemikian rupa agar sesuai dengan kebutuhan mahasiswa.

1. Draf E-Materi

Tabel 4.

Format Draf E-Materi

Nama Mata kuliah :

\begin{tabular}{|l|l|l|}
\hline Display & Isi & Format \\
\hline $\begin{array}{l}\text { Capaian Pembelajaran } \\
(\mathrm{CP})\end{array}$ & $\begin{array}{l}\text { Deskripsi mata kuliah dan } \\
\text { indikator }\end{array}$ & Pdf \\
\hline 1. Teks & Uraian materi & Pdf \\
\hline
\end{tabular}




\begin{tabular}{|l|l|l|}
\hline 2. Video & $\begin{array}{l}\text { Ilustrasi bergerak yang } \\
\text { menampilkan video }\end{array}$ & $\begin{array}{l}\text { Video/ } \\
\text { Flash/ } \\
\text { Gif }\end{array}$ \\
\hline 3. Ppt & $\begin{array}{l}\text { Penjelasan pokok-pokok } \\
\text { pembelajaran }\end{array}$ & Ppt \\
\hline Tugas & Uraian tugas & Pdf \\
\hline Tes Formatif & $\begin{array}{l}\text { Tes pilihan ganda atau } \\
\text { essay }\end{array}$ & Pdf \\
\hline
\end{tabular}

\section{Desain Website}

Website digunakan sebagai sarana penyimpanan media dan asset-aset digital yang mendukung e-materi dengan membuat dengan terlebih dahulu alamat web atau domain serta hosting untuk menyimpan konten (e-materi). Pada tahap ini dilakukan pendaftaran atau registrasi domain internet pada world wide web (www) sebagai alamat $u r l$ sehingga dapat diakses dari jaringan online dimanapun. Pedaftaran alamat url dilakukan di pada penyedia layan hosting dengan membayar biaya langganan yang disesuikan dengan kebutuhan, storage, masa berlaku dan bandwidth. Pada tahapan pengembangan ini peneliti menggunakan blogger.com dengan alasan dapat digunakan secara bebas dan setelah pengembangan protype dari web ini selesai dan siap di transfer ke hosting.

Desain web yang dikembangkan menggunakan single page, dengan tampilan menu-menu yang tersedia pada bar dibagian atas halaman web seperti pada gambar di bawah:

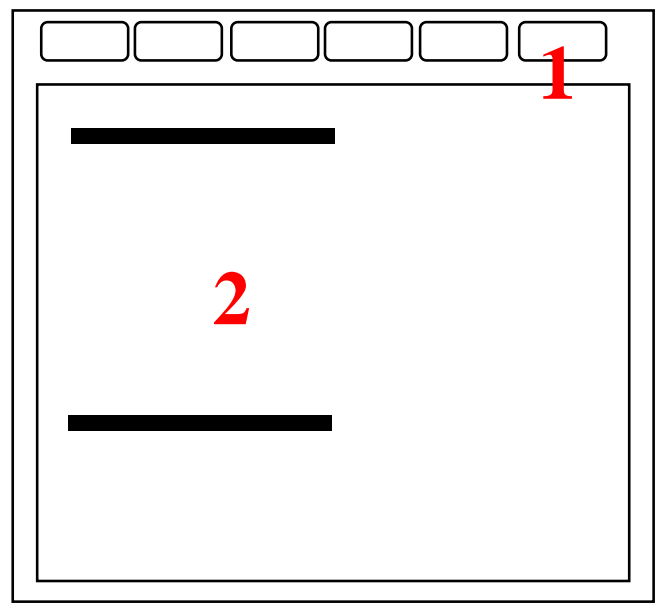


* 1: Menu, 2: Isi

Gambar 2: Tampilan muka website

3. Desain Isi (e-materi)

Isi web yang akan dikembang disusun mengikuti bentuk desain e-materi yang dikemas dalam paket pembelajaran meliputi ; 1) Materi : text,video,slide dll, 2) Tugas, dan Tes (formatif maupun sumatif).

Peket Pembelajaran

1. Meteri text dalam format $p d f$ yang dapat dibaca langsung maupun diunduh untuk dibaca secara offline (luring)

2. Materi vidio yang dapat diputar secara langsung atau dapat dilihat melalui youtube

3. Materi slide berupa file power point yang memuat ringkasan materi yang lebih efisien dan efektif untuk menerangkan materi secara singkat dan dapat di download.

4. Tugas dapat diberikan pada setiap paket pembelajaran baik berupa tugas individu yang dapat di submit secara online (daring) maupun secara langsung (direct)

5. Tes dapat berupa tes pilihan ganda maupun tes isian

Ilustrasi desain isi dapat dilihat pada gambar di bawah:

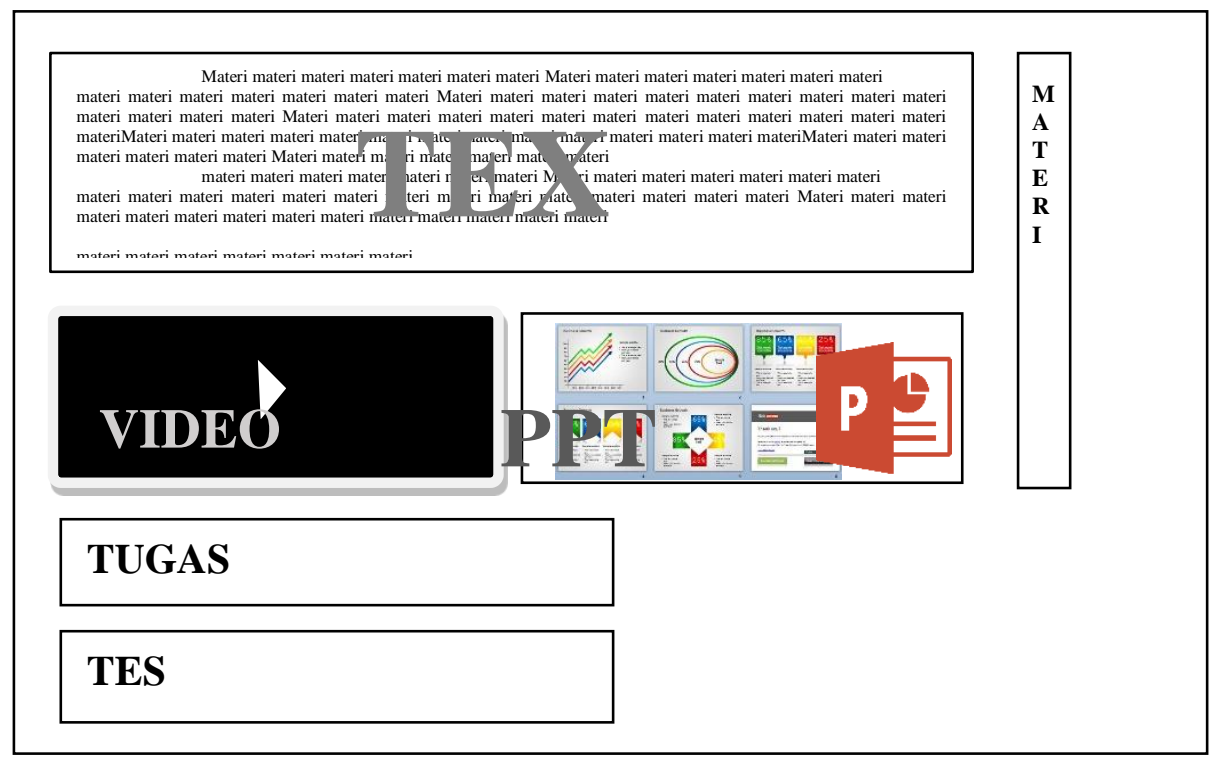

Gambar 3: Tampilan desain isi 


\section{SIMPULAN}

1. Penelitian ini merupakan penelitian Research and Development (RnD) menggunakan model pengembangan Borg and Gall yang terdiri dari Studi Pendahuluan, Studi Pustaka dan Pengembangan (desain, uji coba awal, revisi awal, uji coba lapangan, revisi uji coba lapangan). Yang selanjutnya diujicobakan pada pakar (uji alfa) dan pengguna (uji beta).

2. Produk hasil penelitian ini berupa 1) Hasil studi pendahuluan tentang penggunaan internet di kalangan mahasiswa Universitas Hamzanwadi sangat tinggi berdasarkan hasil penelitian terhadap 100 orang responden $90 \%$ mengakses internet setiap hari.

3. Desain e-materi dalam berbagai format asset-aset digital yang terdiri dari text, video, slide, tugas dan tes dan rancangan desain web yang sesuai dengan user experience e-materi.

\section{DAFTAR PUSTAKA}

Azhar A. (2006).Media pembelajaran.Jakarta: PT Radja Grafindo Perkasa.

Desai, K. (2014). E-Learning. Langlit An International Peer-Reviewed Open Access Journal, 214.

Gall, M. D., Joyce, P., \& Borg, W. R. (2002).Educational research. New York: Omegatype Typography, Lcn.

Hardy. (2015, November 27). Jenis-Jenis Website Berdasarkan Fungsinya. Retrieved from ProgressTech: https://www.progresstech.co.id/blog/jenis-website-fungsi/

Ibrahim, DSM.(2014). The Effects Of The Use Of E-Learning On The Learning Motivation Andachievement In Mathematics Of The Students Of SD Negeri Tahunan Yogyakarta. Jurnal Prima Edukasi, Vol. 2 No. 1, 66-79.

Sudijono, Anas. 2009. Pengantar Statistik Pendidikan. Jakarta: PT Raja Grafindo Persada.

Sumardi, K. dan Supriawan, D. (2011). Model Pembelajaran E-Learning (Lms) Untuk Meningkatkan Pemahaman Materi Termodinamika Teknik Jurnal invotec, Vol. VII No. 1, 53-68.

Tafiardi.(2005). Meningkatkan Mutu Pendidikan Melalui E-Learning. Jurnal Pendidikan Penabur. Vol. IV, No.04, 85-97.

Uwes A.C.,(2017). Model Desain Sistem Pembelajaran Blended. Universitas Negeri Jakarta 